\title{
Plasticicumulans acidivorans gen. nov., sp. nov., a polyhydroxyalkanoate-accumulating gammaproteobacterium from a sequencing-batch bioreactor
}

Correspondence

Mark van Loosdrecht

M.C.M.vanLoosdrecht@tudelft.nl

\author{
Yang Jiang, ${ }^{1}$ Dimitry Yu. Sorokin, ${ }^{1,2}$ Robbert Kleerebezem, ${ }^{1}$ \\ Gerard Muyzer ${ }^{1}$ and Mark van Loosdrecht ${ }^{1}$ \\ ${ }^{1}$ Department of Biotechnology, Delft University of Technology, Julianalaan 67, 2628 BC Delft, \\ The Netherlands
${ }^{2}$ Winogradsky Institute of Microbiology, Russian Academy of Sciences, Prospect 60-let Octyabrya 7/2, 117811 Moscow, Russia

\begin{abstract}
Here, we describe a novel bacterium, strain TUD-YJ37 ${ }^{\top}$, which can accumulate polyhydroxybutyrate $(\mathrm{PHB})$ to more than $85 \%(\mathrm{w} / \mathrm{w})$ dry cell weight. The bacterium was isolated from a mixed-culture bioreactor by using a feast-famine regime and its properties were characterized. Phylogenetic analysis based on full 16S rRNA gene sequences revealed that the isolate is a member of the Gammaproteobacteria, forming an independent, deep phylogenetic lineage. It is most closely related to members of the genera Methylocaldum, Methylococcus and Natronocella, with sequence similarities below $91 \%$. Strain TUD-YJ37 $7^{\top}$ was an obligately aerobic, ovoid, Gram-negative bacterium, motile by means of a polar flagellum. It utilized $\mathrm{C}_{2}-\mathrm{C}_{10}$ fatty acids as carbon and energy sources. The temperature range for growth was $20-35{ }^{\circ} \mathrm{C}$, with an optimum of $30{ }^{\circ} \mathrm{C}$; the $\mathrm{pH}$ range was $6.0-8.0$, without a clear optimum. The major respiratory quinone was Q-8. Polar lipids consisted of diphosphatidylglycerol, phosphatidylglycerol, phosphatidylethanolamine, three unidentified phospholipids, an unidentified aminolipid and another unidentified lipid. The predominant fatty acids in the membrane polar lipids were $\mathrm{C}_{16: 1} \omega 7 c, \mathrm{C}_{16: 0}$ and $\mathrm{C}_{18: 1} \omega 7 c$. The $\mathrm{G}+\mathrm{C}$ content of the genomic DNA was $67.4 \mathrm{~mol} \%$. On the basis of phenotypic, chemotaxonomic and molecular data, the isolate is proposed to represent a novel genus and species, for which the name Plasticicumulans acidivorans gen. nov., sp. nov. is proposed. The type strain of Plasticicumulans acidivorans is TUD-YJ37 ${ }^{\top}$ (=DSM $23606^{\top}=\mathrm{CBS}$ $\left.122990^{\top}\right)$.
\end{abstract}

The intracellular accumulation of polyhydroxyalkanoates (PHAs) is an important ecological feature of bacteria that gives them a selective advantage under varying environmental conditions, especially feast-famine conditions (van Loosdrecht et al., 1997). PHA is also of substantial commercial interest as a raw material for biodegradable plastic (Braunegg et al., 1998; Steinbüchel, 2001). Since genetically engineered bacteria are usually used for the production of PHAs under sterile conditions with defined growth substrates, bioplastics are relatively expensive. An alternative approach could be eco-biotechnology, which aims to produce products by employing mixed cultures under non-sterile conditions, waste streams as substrates

Abbreviations: PHA, polyhydroxyalkanoate; PHB, polyhydroxybutyrate.

The GenBank/EMBL/DDBJ accession number for the 16S-rRNA gene sequence of strain TUD-YJ37 ${ }^{\top}$ is GU206550.

A supplementary figure is available with the online version of this paper. and ecological selection principles to select for the organisms of interest (Kleerebezem \& van Loosdrecht, 2007). In this way, the costs of the processes could be reduced substantially. The often-assumed disadvantage of the use of mixed cultures for PHA production is a relatively low production yield. At the time of writing, the highest reported PHA yields were $90 \%(\mathrm{w} / \mathrm{w})$ of cell dry weight from a genetically modified strain of Escherichia coli (Slater et al., 1988) and only $65 \%(\mathrm{w} / \mathrm{w})$ of dry weight in a mixed culture (Serafim et al., 2004).

In this paper, we describe a novel PHA-producing bacterium that dominated a mixed-culture bioreactor and which represents a new genus and species within the Gammaproteobacteria on the basis of its distinct phenotypic properties and phylogeny.

A 2.51 bioreactor was inoculated with active sludge from a second aerobic stage in the Dokhaven wastewater 
treatment plant in Rotterdam, The Netherlands (September 2004), and was maintained under non-sterile conditions. It was fed with sodium acetate as sole carbon and energy source in a sequencing-batch mode. The reactor was operated at $30{ }^{\circ} \mathrm{C}$ and maintained at $\mathrm{pH} 7.0 \pm 0.05$ by using $1 \mathrm{M} \mathrm{HCl}$ and $1 \mathrm{M} \mathrm{NaOH}$ (Johnson et al., 2009). The concentration of dissolved oxygen (DO) was measured with a DO electrode (Mettler Toledo) and the $\mathrm{pH}$ was monitored with a $\mathrm{pH}$ electrode (Mettler Toledo). DO varied between 30 and $100 \%$ during operation of the reactor. One of the mixed cultures enriched under these conditions was able to generate PHA to $89 \%(\mathrm{w} / \mathrm{w})$ of dry cell weight (Johnson et al., 2009). It was dominated by relatively large ovoid bacteria with a very high content of storage material.

In an attempt to isolate the dominant bacterium, several traditional methods, such as serial dilution-to-extinction and plating, were used, without much success. Therefore, a more sophisticated approach was tried that relied on the physical separation of single cells from a mixed culture using alginate gel beads (Sarma et al., 1998). For this, the reactor biomass was homogenized in a potter tube and serially diluted and cells were mixed with $10 \mathrm{ml}$ sterile sodium alginate solution $(1.5 \% \mathrm{w} / \mathrm{v})$. The mixture was then dropped through a syringe needle into $1 \%(\mathrm{w} / \mathrm{v})$ $\mathrm{CaCl}_{2}$ solution kept on ice. Beads were kept in this cold solution for about $1 \mathrm{~h}$ to harden and then washed with sterile mineral medium. One hundred of the roundest beads were selected randomly for further sequencing-batch cultivation consisting of alternating incubations in the mineral medium $(2 \mathrm{~h})$ and acetate-free mineral medium $(12 \mathrm{~h})$ for 3 days. Individual beads showing formation of microcolonies were harvested, washed in sterile mineral medium and placed in wells of a microtitre plate containing mineral medium. The plate was subsequently incubated at $30{ }^{\circ} \mathrm{C}$. Eventually, individual beads with colonies were homogenized and cells were plated onto mineral agar plates.

The composition of the mineral medium used for isolation was as follows: $12.5 \mathrm{mM}$ sodium acetate trihydrate, $5 \mathrm{mM}$ $\mathrm{NH}_{4} \mathrm{Cl}, 0.1 \mathrm{mM} \mathrm{KH} \mathrm{PO}_{4}, 0.56 \mathrm{mM} \mathrm{MgSO}_{4} .7 \mathrm{H}_{2} \mathrm{O}$ and $0.075 \%(\mathrm{v} / \mathrm{v})$ trace element solution (Vishniac \& Santer, 1957). The acetate-free mineral medium contained the same components as mineral medium but without sodium acetate. All media were autoclaved at $121{ }^{\circ} \mathrm{C}$ for $20 \mathrm{~min}$ before use.

A microcolony from one of the incubated beads resulted in a positive culture dominated by a morphotype similar to the reactor biomass. These cells formed very distinctive, round, dome-like, white-yellowish colonies on mineral agar plates. They were purified by repetitive streaking on solid medium. The resulting isolate was designated strain TUD-YJ $37^{\mathrm{T}}$. When freshly isolated, the strain exhibited two types of colony after repetitive plating from liquid culture. One was similar to the original wild-type colony type, and the other was smoother and flat (Fig. 1a, b). These two

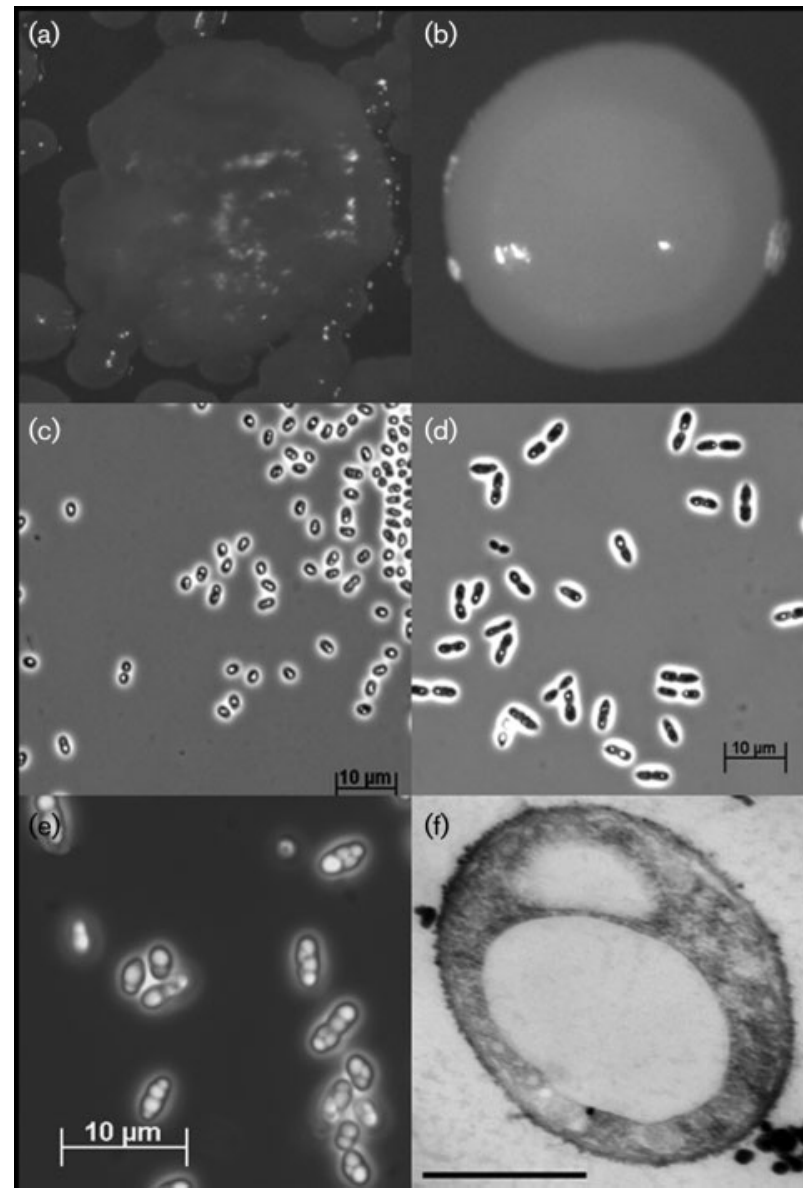

Fig. 1. Micrographs of colonies and cells of strain TUD-YJ37 ${ }^{\top}$. (a) Dome-like rough-type colony; (b) flat smooth-type colony; (c) aggregated coccoid cells from dome-like rough-type colony; (d) elongated cells from a flat smooth-type colony. (e) Cells from bioreactor containing PHB granules; ( $f$ ) electron micrograph of cells containing PHB granules. Bars, $10 \mu \mathrm{m}$ (c-e) and $0.5 \mu \mathrm{m}(\mathrm{f})$.

colony types also corresponded to different modes of growth in liquid culture; the dome-like colonies were mostly formed from aggregated coccoid cells and the flat, smooth type were mostly formed from free elongated cells (Fig. 1c, d). After prolonged maintenance in liquid culture, the culture shifted entirely to the latter variant. The cell morphology of strain TUD-Y $37^{\mathrm{T}}$ varied from coccoid in the reactor biomass to ovoid in freshly isolated cultures; cells were $1.5-1.8 \times 2-3.5 \mu \mathrm{m}$, rarely motile and generally contained large globules of polyhydroxybutyrate (PHB) material (Fig. 1e, f). The alkali lysis test and electron microscopy of thin-sectioned cells revealed a Gramnegative cell-wall type.

The phylogenetic position of the isolate was studied using $16 \mathrm{~S}$ rRNA gene sequence analysis. Genomic DNA was extracted from strain TUD-YJ37 ${ }^{\mathrm{T}}$ using the Ultra Clean soil DNA extraction kit (MoBio Laboratories) following the manufacturer's instructions. Nearly $1400 \mathrm{bp}$ of the $16 \mathrm{~S}$ 
rRNA gene was amplified by using the universal bacteria primers GM3 (5'-AGAGTTTGATCMTGGC-3') and GM4 (5'-TACCTTGTTACGACTT-3'). The DNA fragment obtained was sequenced by Macrogen (Seoul, South Korea) by using primers GM3, GM4, 341F (5'-CCTACGGGAGGCAGCAG-3'), 907F (5'-AAACTCAAAKGAATTGACGG-3') and 907RM (5'-CCGTCAATTCMTTTGAGTTT$\left.3^{\prime}\right)$. Sequence similarity was initially analysed using BLAST. The highest similarity was obtained with uncultured bacterial clones from active sludge in Australia (Schroeder et al., 2009). In addition, a similarity analysis was performed against sequences of type strains on the EzTaxon server (http://www. eztaxon.org/; Chun et al., 2007). The nearest cultured relatives were members of the genera Methylocaldum (highest sequence similarity 91.0\%), Methylococcus (90.6\%), Natronocella (90.5\%), Thiocapsa (90.2\%), Thioalkalivibrio (90.1\%), Nitrosococcus (90.1\%) and Ectothiorhodospira (90.1\%). A phylogenetic tree was reconstructed from the alignment using the ARB software program (Ludwig et al., 2004) and the neighbour-joining algorithm with Felsenstein's correction (Fig. 2).

Respiratory quinones and polar lipids were analysed according to the method described by Tindall (1990a, b) by the Identification Service of the DSMZ and Dr B. J. Tindall (DSMZ, Braunschweig, Germany). The main quinone component was Q-8 (>96\%), which is characteristic of many gammaproteobacteria (Yokota et al., 1992). Major polar lipids were phosphatidylglycerol and phosphatidylethanolamine, with diphosphatidylglycerol, three unidentified phospholipids, an unidentified aminolipid and another unidentified lipid present in smaller amounts (Supplementary Fig. S1, available in IJSEM Online).

For analysis of fatty acid methyl esters, polar lipids were extracted from dry cell material with acidic methanol. The resulting methyl esters were analysed by GC-MS using the Sherlock Microbial Identification system (MIDI Inc.) according to Zhilina et al. (1997). The major cellular fatty acids of strain TUD-YJ37 $37^{\mathrm{T}}$ were $\mathrm{C}_{16: 1} \omega 7 c(43 \%), \mathrm{C}_{16: 0}$ $(30 \%)$ and $\mathrm{C}_{18: 1} \omega 7 c(18 \%)$, typical of proteobacteria. Table 1 shows the detailed fatty acid composition of strain TUD-YJ $37^{\mathrm{T}}$.

The $\mathrm{G}+\mathrm{C}$ content of genomic DNA extracted from $1 \mathrm{~g}$ wet cell biomass according to Marmur (1961) was determined by the thermal denaturation technique (Marmur \& Doty 1962). The value obtained was $67.4 \mathrm{~mol} \%$.

Physiological characteristics of strain TUD-YJ $37^{\mathrm{T}}$ were examined in batch liquid culture. The organism grew on acetate as substrate at $20-35{ }^{\circ} \mathrm{C}$ (optimum $30{ }^{\circ} \mathrm{C}$ ) and at $\mathrm{pH}$ 6-8. Growth and respiration of cells were inhibited completely by $\mathrm{NaCl}$ and $\mathrm{KCl}$ at concentrations above $150 \mathrm{mM}$. The bacterium could not grow anaerobically with nitrate, but could reduce nitrate to nitrite. Substrate utilization tests were performed in liquid acetate-free mineral medium mixed with carbon sources listed in Table 2. The results demonstrated that strain TUD-YJ $37^{\mathrm{T}}$ was specialized for use of simple fatty acids $\left(\mathrm{C}_{2}-\mathrm{C}_{10}\right)$ and was able to use pyruvate, succinate, lactate, fumarate and ethanol as carbon sources. PHA granules in cells could be observed with different tested fatty acids. Maximum PHB content ( $89 \%$ w/ w) was obtained when acetate was the sole carbon source and ammonia was deficient. With acetate as carbon source, strain TUD-YJ $37^{\mathrm{T}}$ could use ammonia, nitrate and complex organic nitrogen (yeast extract) as nitrogen sources. Oxidase $[1 \%(\mathrm{w} /$ v) tetramethyl $p$-phenylenediamine] and catalase [3\%(v/v) $\mathrm{H}_{2} \mathrm{O}_{2}$ ] tests were positive. The most important phenotypic characteristics of strain TUD-Y $337^{\mathrm{T}}$ are compared with those of its closest relatives in Table 2.

The overall results of phenotypic and phylogenetic analyses suggest that the novel PHA-accumulating bacterium from a bioreactor is substantially different from other gammaproteobacteria described so far. Therefore, it is proposed to be accommodated in a novel genus and species, Plasticicumulans acidivorans gen. nov., sp. nov.

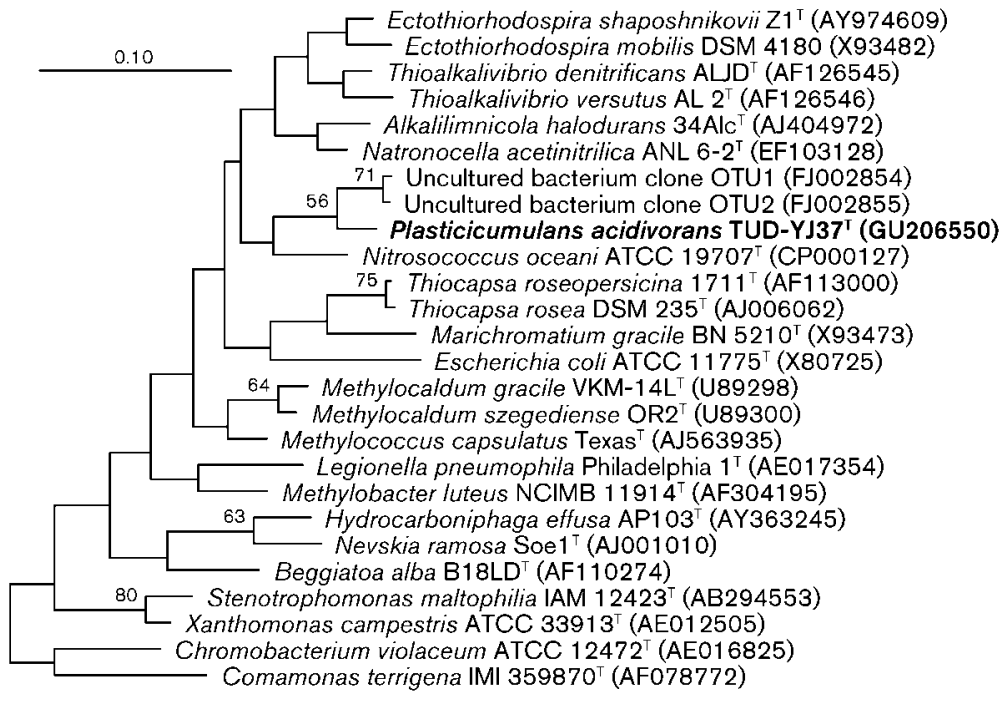

Fig. 2. Neighbour-joining tree reconstructed from 16S rRNA gene sequences showing phylogenetic relationships between strain TUDY $37^{\top}$ and selected members of the Gammaproteobacteria. Bootstrap values $>50 \%$ are indicated at branch-points. Bar, 0.1 substitutions per nucleotide position. 
Table 1. Cellular fatty acids of strain TUD-YJ37 ${ }^{\top}$

Values are percentages of total fatty acids. Fatty acids in bold represent predominant types.

\begin{tabular}{|lc|}
\hline Fatty acid & Proportion (\%) \\
\hline $\mathrm{C}_{12: 0}$ & 1.2 \\
$\mathrm{C}_{12: 0} 3-\mathrm{OH}$ & 0.2 \\
iso- $_{14: 0}$ & 0.1 \\
$\mathrm{C}_{14: 1} \omega 6$ & 1.4 \\
$\mathrm{C}_{14: 0}$ & 2.7 \\
$\mathrm{C}_{15: 0}$ & 0.2 \\
iso- $_{16: 0}$ & 0.3 \\
$\mathrm{C}_{16: 1} \omega 7 c$ & $\mathbf{4 3 . 3}$ \\
$\mathrm{C}_{16: 1} \omega 7 t$ & 0.4 \\
$\mathrm{C}_{16: 0}$ & $\mathbf{2 9 . 9}$ \\
$\mathrm{C}_{18: 1} \omega 9$ & 0.2 \\
$\mathrm{C}_{18: 1} \omega 7 c$ & $\mathbf{1 8 . 0}$ \\
$\mathrm{C}_{18: 1} \omega 5 t$ & 0.1 \\
$\mathrm{C}_{18: 0}$ & 1.7 \\
$\mathrm{C}_{18: 1} 3-\mathrm{OH}$ & 0.1 \\
Total & 100.0 \\
\hline
\end{tabular}

\section{Description of Plasticicumulans gen. nov.}

Plasticicumulans (Plas'ti.ci.cu'mu.lans. N.L. n. plasticum plastic; L. part. adj. cumulans accumulating; N.L. part. adj. used as a masc. n. Plasticicumulans accumulating plastic).

Gram-negative ovoids, obligately aerobic and heterotrophic, with preference for simple fatty acids $\left(\mathrm{C}_{2}-\mathrm{C}_{10}\right)$ as carbon and energy sources. High capacity to store PHAs. Mesophilic and neutrophilic. Identified membrane polar lipids include diphosphatidylglycerol, phosphatidylglycerol, phosphatidylethanolamine, three unidentified phospholipids, an unidentified aminolipid and another unidentified lipid. The major cellular fatty acids are $\mathrm{C}_{16: 1} \omega 7 c, \mathrm{C}_{16: 0}$ and $\mathrm{C}_{18: 1} \omega 7 c$. The DNA $G+C$ content of the type strain of the type species is $67.4 \mathrm{~mol} \%$. Belongs to the Gammaproteobacteria, with the genera Methylocaldum, Methylococcus and Natronocella as closest phylogenetic neighbours. The type species is Plastici cumulans acidivorans.

\section{Description of Plasticicumulans acidivorans sp. nov.}

Plasticicumulans acidivorans (a.ci.di.vo'rans. N.L. n. acidum an acid; L. part. adj. vorans eating, devouring; N.L. part. adj. acidivorans acid-devouring).

Table 2. Comparison of the properties of strain TUD-YJ3 $37^{\top}$ and its nearest phylogenetic relatives

Taxa: 1, strain TUD-YJ37 ; 2, Methylocaldum (data for three species from Bodrossy et al., 1997); 3, Methylococcus (eight species; Hazeu et al., 1980; Bowman et al., 1993); 4, Natronocella acetinitrilica (Sorokin et al., 2007); 5, Thiocapsa (six species; Imhoff et al., 1982; Imhoff, 1984; Asao et al., 2007); 6, Thioalkalivibrio (nine species; Sorokin et al., 2001); 7, Nitrosococcus (two species; Watson, 1971); 8, Ectothiorhodospira (ten species; Asselineau \& Trüper, 1982; Imhoff, 2006; Gorlenko et al., 2009). Numbers in parentheses represent numbers of species giving the result shown. ND, No data available.

\begin{tabular}{|c|c|c|c|c|c|c|c|c|}
\hline Characteristic & 1 & 2 & 3 & 4 & 5 & 6 & 7 & 8 \\
\hline Cell shape $(\mathrm{s}) \dagger$ & $\mathrm{CD}, \mathrm{OD}$ & C, PR & $C, \mathrm{R}$ & $\mathrm{R}$ & $\mathrm{C}$ & $\mathrm{R}, \mathrm{SP}$ & $C, E$ & $\mathrm{O}, \mathrm{R}$ \\
\hline Nutritional type $\neq$ & $\mathrm{COH} \varsigma$ & $\mathrm{OM}$ & OM & $\mathrm{COH}$ & ANP & OCLA & OCLA & ANP \\
\hline Halophily & - & ND & + & + & - & + & + & + \\
\hline Thermophily & - & + & $+(3)$ & ND & - & $+(2)$ & - & - \\
\hline Denitrification & - & ND & - & - & ND & + & ND & ND \\
\hline Reduction of nitrate to nitrite & + & $\mathrm{ND}$ & $+(3)$ & + & ND & + & $\mathrm{ND}$ & ND \\
\hline Major quinone(s)॥ & Q-8 & ND & MQ-8 & ND & Q-8 & Q-8 & ND & MK-7, Q-7 (or Q-8) \\
\hline $\begin{array}{l}\text { Dominant phospholipid fatty } \\
\text { acids }\end{array}$ & $\mathrm{C}_{16: 1}, \mathrm{C}_{16: 0}, \mathrm{C}_{18: 1}$ & $\begin{array}{l}C_{16: 0} \\
C_{16: 1}\end{array}$ & $\begin{array}{l}\mathrm{C}_{16: 0} \\
\mathrm{C}_{16: 1}\end{array}$ & $\begin{array}{l}\mathrm{C}_{18: 1} \\
\mathrm{C}_{16: 0}\end{array}$ & $\mathrm{ND}$ & $\mathrm{ND}$ & ND & $C_{18: 1}, C_{16: 0}, C_{16: 1}$ \\
\hline
\end{tabular}

${ }^{\star}$ Similarity between strain TUD-YJ $37^{\mathrm{T}}$ and the type strain of the type species.

$\dagger_{\mathrm{C}}$, Coccus; CD, coccoid; E, ellipsoid; O, oval; OD, ovoid; PR, pleomorphic rod; R, rod; sP, spirillum.

‡ANP, Anaerobic phototroph; COH, chemo-organoheterotroph; OCLA, obligate chemolithoautotroph; OM, obligate methanotroph.

$\S$ See species description for carbon and energy sources.

IIMK, Menaquinone; MQ, methyleneubiquinone; Q, ubiquinone.

SCL, Cardiolipin; DPG, diphosphatidylglycerol; PC, phosphatidylcholine; PE, phosphatidylethanolamine; PG, phosphatidylglycerol; AL, unidentified aminolipid; PL, unidentified phospholipid; L, unidentified lipid. 
Displays the following properties in addition to those given for the genus. Cell shape varies from coccoid to ovoid, 1.5$1.8 \times 3-5 \mu \mathrm{m}$. Forms two colony variants, dome-like rough and flat smooth, whitish-yellowish, up to $3 \mathrm{~mm}$ in diameter after $72 \mathrm{~h}$ of incubation at $30^{\circ} \mathrm{C}$. Accumulates up to $89 \%(\mathrm{w} / \mathrm{w})$ PHA, with storage polymers in the form of large intracellular granules. Utilizes the following organic compounds as carbon and energy sources: acetate, propionate, butyrate, valerate, caproate, heptanoate, octanoate, nonanoate, decanoate, pyruvate, succinate, lactate, fumarate, ethanol, malate and yeast extract. The following compounds are not utilized: hexoses (including glucose), pentoses (including arabinose), methanol, formate and $\mathrm{H}_{2}$. Ammonium and nitrate serve as nitrogen sources. Oxidase and catalase are positive. Hydrolysis of aesculin and gelatin is negative. Grows at $20-35{ }^{\circ} \mathrm{C}$ (optimum $30{ }^{\circ} \mathrm{C}$ ) and $\mathrm{pH} 6-8$. Salt-sensitive; growth and respiration are inhibited in the presence of $150 \mathrm{mM} \mathrm{NaCl}$ or $\mathrm{KCl}$. Nitrate is reduced to nitrite. The major respiratory quinone is Q-8.

The type strain is TUD-YJ37 ${ }^{\mathrm{T}}\left(=\mathrm{DSM} 23606^{\mathrm{T}}=\mathrm{CBS}\right.$ $122990^{\mathrm{T}}$ ), isolated from a sequencing-batch bioreactor fed with acetate.

\section{Acknowledgements}

These investigations were supported by the Netherlands Organization for Scientific Research (NWO) in the NWO-ACTS research programme B-Basic and by the Foundation for Technical Sciences (STW). We thank our co-workers, Ben Abbas, Kees van Sluis and Samira Mohamad, for their help in this study.

\section{References}

Asao, M., Takaichi, S. \& Madigan, M. T. (2007). Thiocapsa imhoffii, sp. nov., an alkaliphilic purple sulfur bacterium of the family Chromatiaceae from Soap Lake, Washington (USA). Arch Microbiol 188, 665-675.

Asselineau, J. \& Trüper, H. G. (1982). Lipid composition of six species of the phototrophic bacterial genus Ectothiorhodospira. Biochim Biophys Acta 712, 111-116.

Bodrossy, L., Holmes, E. M., Holmes, A. J., Kovács, K. L. \& Murrell, J. C. (1997). Analysis of $16 \mathrm{~S}$ rRNA and methane monooxygenase gene sequences reveals a novel group of thermotolerant and thermophilic methanotrophs, Methylocaldum gen. nov. Arch Microbiol 168, 493503.

Bowman, J. P., Sly, L. I., Nichols, P. D. \& Hayward, A. C. (1993). Revised taxonomy of the methanotrophs: description of Methylobacter gen. nov., emendation of Methylococcus, validation of Methylosinus and Methylocystis species, and a proposal that the family Methylococcaceae includes only the group I methanotrophs. Int J Syst Bacteriol 43, 735-753.

Braunegg, G., Lefebvre, G. \& Genser, K. F. (1998). Polyhydroxyalkanoates, biopolyesters from renewable resources: physiological and engineering aspects. J Biotechnol 65, 127-161.

Chun, J., Lee, J.-H., Jung, Y., Kim, M., Kim, S., Kim, B. K. \& Lim, Y. W. (2007). EzTaxon: a web-based tool for the identification of prokaryotes based on $16 \mathrm{~S}$ ribosomal RNA gene sequences. Int J Syst Evol Microbiol 57, 2259-2261.
Gorlenko, V. M., Bryantseva, I. A., Rabold, S., Tourova, T. P., Rubtsova, D., Smirnova, E., Thiel, V. \& Imhoff, J. F. (2009). Ectothiorhodospira variabilis sp. nov., an alkaliphilic and halophilic purple sulfur bacterium from soda lakes. Int J Syst Evol Microbiol 59, 658-664.

Hazeu, W., Batenburg-van der Vegte, W. H. \& Bruyn, J. C. (1980). Some characteristics of Methylococcus mobilis sp. nov. Arch Microbiol 124, 211-220.

Imhoff, J. F. (1984). Quinones of phototrophic purple bacteria. FEMS Microbiol Lett 25, 85-89.

Imhoff, J. F. (2006). The family Ectothiorhodospiraceae. In The Prokaryotes: a Handbook on the Biology of Bacteria, 3rd edn, vol. 6, pp. 874-886. Edited by M. Dworkin, S. Falkow, E. Rosenberg, K. H. Schleifer \& E. Stackebrandt. New York: Springer.

Imhoff, J. F., Kushner, D. J., Kushwaha, S. C. \& Kates, M. (1982). Polar lipids in phototrophic bacteria of the Rhodospirillaceae and Chromatiaceae families. J Bacteriol 150, 1192-1201.

Johnson, K., Jiang, Y., Kleerebezem, R., Muyzer, G. \& van Loosdrecht, M. C. M. (2009). Enrichment of a mixed bacterial culture with a high polyhydroxyalkanoate storage capacity. Biomacromolecules 10, 670-676.

Kleerebezem, R. \& van Loosdrecht, M. C. M. (2007). Mixed culture biotechnology for bioenergy production. Curr Opin Biotechnol 18, 207-212.

Ludwig, W., Strunk, O., Westram, R., Richter, L., Meier, H., Yadhukumar, Buchner, A., Lai, T., Steppi, S. \& other authors (2004). ARB: a software environment for sequence data. Nucleic Acids Res 32, 1363-1371.

Marmur, J. (1961). Procedure for isolation of deoxyribonucleic acid from micro-organisms. J Mol Biol 3, 208-218.

Marmur, J. \& Doty, P. (1962). Determination of the base composition of deoxyribonucleic acid from its thermal denaturation temperature. J Mol Biol 5, 109-118.

Sarma, C., Sen, A., Varghese, R. \& Misra, A. K. (1998). A novel technique for isolation of Frankia and generation of single-spore cultures. Can J Microbiol 44, 490-492.

Schroeder, S., Petrovski, S., Campbell, B., Mcllroy, S. \& Seviour, R. (2009). Phylogeny and in situ identification of a novel gammaproteobacterium in activated sludge. FEMS Microbiol Lett 297, 157-163.

Serafim, L. S., Lemos, P. C., Oliveira, R. \& Reis, M. A. M. (2004). Optimization of polyhydroxybutyrate production by mixed cultures submitted to aerobic dynamic feeding conditions. Biotechnol Bioeng 87, 145-160.

Slater, S. C., Voige, W. H. \& Dennis, D. E. (1988). Cloning and expression in Escherichia coli of the Alcaligenes eutrophus $\mathrm{H} 16$ poly- $\beta$ hydroxybutyrate biosynthetic pathway. J Bacteriol 170, 4431-4436.

Sorokin, D. Yu., Lysenko, A. M., Mityushina, L. L., Tourova, T. P., Jones, B. E., Rainey, F. A., Robertson, L. A. \& Kuenen, G. J. (2001). Thioalkalimicrobium aerophilum gen. nov., sp. nov. and Thioalkalimicrobium sibericum sp. nov., and Thioalkalivibrio versutus gen. nov., sp. nov., Thioalkalivibrio nitratis sp. nov. and Thioalkalivibrio denitrificans sp. nov., novel obligately alkaliphilic and obligately chemolithoautotrophic sulfur-oxidizing bacteria from soda lakes. Int $J$ Syst Evol Microbiol 51, 565-580.

Sorokin, D. Yu., van Pelt, S., Tourova, T. P., Takaichi, S. \& Muyzer, G. (2007). Acetonitrile degradation under haloalkaline conditions by Natronocella acetinitrilica gen. nov., sp. nov. Microbiology 153, 11571164.

Steinbüchel, A. (2001). Perspectives for biotechnological production and utilization of biopolymers: metabolic engineering of polyhydroxyalkanoate biosynthesis pathways as a successful example. Macromol Biosci 1, 1-24. 
Tindall, B. J. (1990a). A comparative study of the lipid composition of Halobacterium saccharovorum from various sources. Syst Appl Microbiol 13, 128-130.

Tindall, B. J. (1990b). Lipid composition of Halobacterium lacusprofundi. FEMS Microbiol Lett 66, 199-202.

van Loosdrecht, M. C., Pot, M. A. \& Heijnen, J. J. (1997). Importance of bacterial storage polymers in bioprocesses. Water Sci Technol 35 (1),41-47.

Vishniac, W. \& Santer, M. (1957). The thiobacilli. Bacteriol Rev 21, 195-213.
Watson, S. W. (1971). Taxonomic considerations of the family Nitrobacteraceae Buchanan. Int J Syst Bacteriol 21, 254-270.

Yokota, A., Akagawa-Matsushita, M., Hiraishi, A., Katayama, Y., Urakami, T. \& Yamasato, K. (1992). Distribution of quinone systems in microorganisms: gram-negative eubacteria. Bull Jpn Fed Cult Coll 8, 136-171.

Zhilina, T. N., Zavarzin, G. A., Rainey, F. A., Pikuta, E. N., Osipov, G. A. \& Kostrikina, N. A. (1997). Desulfonatronovibrio hydrogenovorans gen. nov., sp. nov., an alkaliphilic, sulfate-reducing bacterium. Int J Syst Bacteriol 47, 144-149. 